\title{
Public Speaking in EFL Postgraduate Courses in Italy: A Case Study with Students of Political Science, University of Genoa
}

\author{
Francesco Pierini ${ }^{1}$ \\ ${ }^{1}$ Department of Political Science, University of Genoa, Italy \\ Correspondence: Francesco Pierini, Department of Political Science, University of Genoa, Italy.
}

Received: May 19, 2020

Accepted: June 5, 2020

Online Published: July 15, 2020

doi: 10.5539/elt.v13n8p127

URL: https://doi.org/10.5539/elt.v13n8p127

\begin{abstract}
The teaching of soft skills in EFL postgraduate courses is increasingly part of the Italian university curricula, albeit with some delay compared to foreign universities. Postgraduate English language courses need to focus on the use of language in foreseeable situations by creating opportunities to use the language in public contexts. Meetings, presentations, debates are the activities that young people will increasingly be called upon to engage in. Rather than solely on theoretical knowledge learned previously, these activities develop the practical use of language, in front of an audience, with a structured discourse and with some emphasis on the non-verbal elements of communication. Although these aspects may appear daunting to students, more often than not, they have been able to overcome their anxiety, not only in relation to the embarrassment of speaking a foreign language in public, but even to the mere act of speaking in public, which represents an obstacle in itself. In this study a case of Italian postgraduate students of Political Science was carried out and analysed.
\end{abstract}

Keywords: anxiety, public speaking, presentation, English, Italian

\section{Introduction}

In an age which has often been defined as globalized and where communication can take place very easily, not only before a real audience but also virtually, the need for effective public speaking has become crucial. Be it in the form of a corporate presentation, delivering a paper at a conference, presiding over a board meeting, or any other form of speech delivery, speaking in public has taken on a strategic role in interpersonal relationships because this level of interaction is increasingly common. It is evidence of our ability to master communication at a time when effective relationships can make a difference in politics, business, diplomacy and any other sphere of human life. Particularly in business, the ability to deliver a presentation/a speech has become more and more widely appreciated by companies, that have transformed this activity into a "ceremony" that belongs to a consolidated business routine (Souter, 2007). Therefore, this ability can neither be undervalued nor taken for granted, especially when it involves speaking in a foreign language.

Students of foreign languages in Italy sometimes complain that too much focus is given to the teaching of grammar and activities that do not really prepare them to become fluent speakers. It is not my intention to investigate this aspect in depth here, because that would involve giving a completely different perspective to my research. However, starting from my personal experience as a teacher and trying to take stock of the students' desiderata that I have collected during my teaching activity, some problems have consistently emerged: on the one hand, the lack of speaking opportunities in everyday life which gives rise to poor communicative skills, combined with a sort of anxiety which is often present when having to use a foreign language in oral communication. These are an evident sign of the students' awareness of being at a disadvantage when communicating in English. These two aspects will be discussed later as they represent the core issue of this investigation.

\subsection{English Proficiency among Italian Students}

We all know that learning a foreign language requires a great deal of practice and commitment and most students are aware - at least in Italy but not only - that often their level of English is not adequate to meet firstly the standards demanded by the job market, but even the skills required in general conversation. As far as Italy is concerned, it is important to show the state of the art from a worldwide survey conducted by EF of the English Proficiency Index 2013 (EPI), which calculates the average adult English skills for each country. Results are far 
from encouraging for Italy. Indeed, from this report, based on the data from the 750,000 adults who took the EF English tests in 2012, together with the data collected in the preceding six years (2007 to 2012) from nearly five million adults, EF was able to produce an international country ranking in English proficiency among adults (Note 3). These levels fall into five bands:

1) very high proficiency

2) high proficiency

3) moderate proficiency

4) low proficiency

5) very low proficiency.

Italy ranked $32^{\text {nd }}$ and is in the $4^{\text {th }}$ band, along with France, but very far from top performing nations in Europe such as Scandinavian countries as well as Central European countries. Moreover, according to another study conducted by ISTAT (2014) these results seem to be confirmed (Note 4). The survey is about the use and knowledge of Italian, dialects and foreign languages in Italy. Results show that, although out of the seven age groups considered, two of them - 18-24-year-olds and 25-34-year-olds - declare they know a foreign language, $85.5 \%$ and $77.6 \%$ respectively, of which English accounts for $80.4 \%$ and $64.6 \%$, their opinion is that their level of English is rather low.

\section{Literature Review}

Most of the literature produced on the issue of public speaking in EFL classes comes from Asian scholars and most studies focus on China and the Far East (Yaikhong and Usaha, 2012; Liu, 2006; Luo, 2014), but some interesting research also comes from Eastern European countries (Janulevičienè \& Kavaliauskienè, 2012; Tercan \& Dikilitaş (2012)). As a matter of fact Chinese scholars are very concerned with the teaching of English as a foreign language (EFL) since as Cooke observes "[it] has become a nationwide endeavor pursued at all academic levels [and] there has been an explosion in the development of public school English programs and private English language schools throughout China" (Cooke, 2007, p.X). Most studies focus on various aspects but mainly on the psychological characteristics of public speaking (anxiety) and public speaking techniques (presentation structure, linguistic and extra-linguistic features of the speech).

As regards more specifically the aspect of anxiety, the most recent literature outlines that the main underlying reasons "appear to be lack of confidence, unfamiliar situation, sense of isolation, self-consciousness, fear of looking foolish, and fear of consequences, i.e. being judged by others" (Kavaliauskiené, 2006). A study conducted among international students in a Malaysian university highlights that "the lecturers' strategies and students' reactions to their strategies are not related to cultural backgrounds but to affective filters and learning skills common to all human beings" (Zhiping and Paramasivam, 2013). After all, sociologist Erving Goffman affirms that in all cultures of the world there is an idea of the individual public face that corresponds to a public sense of positive identity and self-esteem. Social interactions encourage people to give the best of themselves through "demonstrations" designed to highlight and defend their own qualities, characteristics and dignity. In fact, the 'face' is being continuously monitored and subject to the judgment of others; since the face is public, it is governed by others, as if to signify that our image is the result of the way other people treat us (Goffman, 1959; 1967). In practical teaching experience, the affective-humanistic approach draws inspiration from the personological stances suggested by psychotherapist Rogers. His so-called Person-Centred Approach is based on the fact that.

Individuals have within themselves vast resources for self-understanding and for altering their self-concepts, basic attitudes and self-directed behavior; these resources can be tapped if a definable climate of facilitative psychological attitudes can be provided (Rogers, 1980, p.115).

Porcelli states that human physicality is wholly involved in the learning process since teachers never deal with pure intelligence. The psychomotor domain implies that the brain is connected to the hearing and vocal apparatus. Speech is in turn regulated by breath, gesture, posture, proxemics and so on. So, since the whole body is involved in an all-encompassing language experience, it is this total experience that becomes rooted in the learner and can turn into skills and abilities (Porcelli, 2004, p.8). As both verbal and non-verbal elements are present in any interpersonal communication the latter cannot be underestimated in public speaking activities, since presenters are in the spotlight for a certain amount of time. 


\section{Purpose of this Work}

In Italy, as a general rule, EFL courses tend to have too many students and too few tools for teachers to help them practice English orally as much as would be desirable; most work focuses on listening, grammar and the study of English for Specific Purposes (ESP) depending on the course taken by students either in their Bachelor's or Master's Degree.

The idea of providing students with an English course based on public speaking came from my personal conviction that getting them acquainted with soft skills and public speaking was helpful for them to understand whether they were generally afraid of speaking in public or if their anxiety came from speaking English in public. In addition, this approach would make them not only aware of the extra-linguistic skills involved in speech-delivery, but also allow the students to use them effectively: non-verbal communication, computer skills, peer-assessment, etcetera. It is by no means insignificant that after university, students will be expected to use English in different cultural systems and contexts, and speaking before an audience reinforces communication as a whole. The process of communication is a voluntary, planned and conscious act of exchanging "messages" in order to achieve one's ends (Balboni, 1999, p.23), which is summed up by the author as «scambiare messaggi vincenti» (Note 1).

The aim of this research is to analyse the course as it took shape, developed and concluded, in order to see if teaching public speaking was a worthwhile activity, whether it can be improved and how, and get the feedback from the students who were involved in the course. The issues I intend to address in this article are the weak points in the public speaking of some Italian postgraduate learners and whether public speaking can be regarded as a meaningful activity in language learning at a postgraduate level.

\section{Research Method}

The research is based on the academic year 2018/2019. The method deemed most suitable in my research to gather data was by means of a questionnaire. The sample was limited and the arrangement of the study is the result of a "biased" observer, deeply involved in the matter as I was, given that I was responsible for the course, gave the students the principles of public speaking, assessed their performance and submitted them an (anonymous) questionnaire to have feedback on the experience. In the following paragraph I will provide the reader with some background information about the English course as well as how the students' presentations were managed.

\subsection{Course Syllabus}

English language II is an upper-intermediate course aimed at students specialising in a Masters in either International Sciences or Public Policy and Administration, designed to provide students with a B2 level of the CEFR (Note 2). All of the students had previously attended an annual English language course (English language I) during their undergraduate studies, designed to provide them with a B1 level of the CEFR.

The main theme in the first semester was change management (as a soft skill). Reading of the book Who moved my cheese? by Spencer Johnson was followed by debates about dealing with change, for example the ways in which people cope with change, why it is normally feared, and whether it is - in the form of adapting to a new status quo - indispensable both at work and in life. This helped students 1) to use English in class, despite the difficulties some had in expressing their point of view and 2) to prepare for a new form of teaching which would be introduced at a later stage.

In the second semester the main theme was public speaking and the students were told they would have to prepare their own presentations. First, several lessons were devoted to studying the basics of public speaking: how to structure a presentation (opening, body, conclusion), how to present it (technical equipment, objects, slides and videos), how to use words (abstraction, concretion, denotation, connotation, imagery, inclusiveness), how to use persuasion (rhetoric, credibility, empathy), how to use other channels of communication (body language, proxemics, eye contact, posture, gestures), and how to assess a performance (items usually evaluated during a speech).

Then, we dedicated some lessons to watching videos by top speakers, which allowed students to do listening activities and vocabulary learning, but also observe how professional performers behave on the stage, how they face the public, how they use their voice and body language. After each video a conversation followed where they were encouraged to give an opinion. 


\subsection{Participants}

The participants were 22 students of the course, 20 were Italian, 1 was Albanian and 1 was Chinese. Students were informed of the public speaking project at the end of the first semester. They were asked to think about a topic of their choice.

\subsection{Procedure}

Each presentation was to be given in 15 minutes (as a maximum) and the topic was to be chosen by each student based on his/her personal interests. Stylistically speaking the presentation was expected to contain both elements of the informative and the persuasive type. The presentation could be delivered on a whiteboard, using a laptop/PC and a projector, or just extemporaneously. Prior to the presentation sessions some principles were settled on which students and teacher had to agree upon.

Each presentation would be followed by the speaker's personal feedback (Self-assessment), by their fellow students' feedback (Peer-assessment) and by the teacher's feedback (Teacher-assessment). This would be based on the structure of the presentation (title, purpose, introduction, body, conclusion), English language skills (grammar, vocabulary, pronunciation), the implementation of persuasive skills (use of rhetoric) and extra-linguistic skills (management of non-verbal language). Participants (Ps) were spread over 6 dates. The teacher would give marks at the end of all presentations. On May 2, 2019 the teacher sent the participants a questionnaire to have their feedback about the experience of public speaking.

\subsection{Questionnaire}

The questionnaire delivery was managed anonymously in order to give students the utmost freedom to answer. Students had to answer 8 closed-ended questions choosing from a list of four pre-selected options that left no space for personal expression. At the end of the questionnaire an optional open-ended question allowed students to add something personal that might have been neglected in the previous part. Questions were asked in English with Italian translation. This is the structure of the questionnaire:

4.4.1 Do you Like Giving Public Presentations/delivering a Speech in your Native Language?

Ti piace fare presentazioni in pubblico/tenere discorsi nella tua lingua madre?

Yes (si)

Not much (non molto)

No (no)

4.4.2 How often have you Given a Public Presentation/a Speech in Everyday Life?

Quante volte ti capita di fare una presentazione in pubblico/di tenere un discorso nella vita di tutti i giorni?

\begin{tabular}{l}
\hline Never \\
(Mai) \\
Rarely \\
(Di rado) \\
Occasionally \\
(Qualche volta) \\
Often or quite often \\
(Spesso o molto spesso) \\
\hline
\end{tabular}

4.4.3 How did you Feel When you were Asked to Give a Public Presentation in your English Class?

Come ti sei sentito quando ti è stato proposto di fare una presentazione in pubblico in inglese con la tua classe?

Irritated
(Irritato)
Calm
(Calmo)
Slightly nervous
(Un po' nervoso)
Very nervous
(Molto nervoso)


4.4.4 How do you usually Feel When you have to Speak English?

Come ti senti di solito quando devi parlare in inglese?

I feel confident and relaxed

(Mi sento sicuro e rilassato)

I feel slightly nervous but can cope

(Sono un po' nervoso ma fondamentalmente sto bene)

I get nervous and confused

(Divento nervoso e mi confondo)

I start to panic

(Mi viene il panico)

4.4.5 How did you Feel When you Gave your English Presentation/speech in Front of the Class?

Come ti sentivi quando hai fatto la tua presentazione/tenutoil discorso in inglese di fronte alla tua classe?

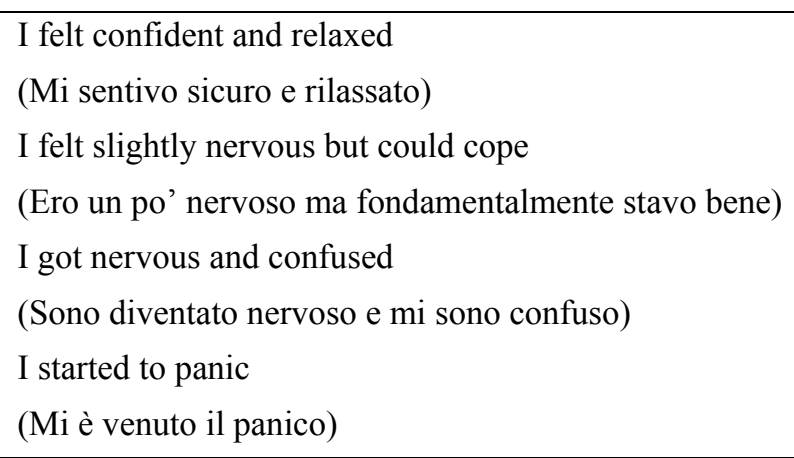

4.4.6 What was your Main Difficulty in Giving your Presentation/speech in Front of the Class?

Qual è stata la principale difficoltà che hai incontrato nel fare la tua presentazione/nel tenere il tuo discorso di fronte alla tua classe?
Fear of speaking in public
(La paura di parlare in pubblico)
Fear of speaking in English
(La paura di parlare in inglese)
Reaction of the teacher
(La reazione dell'insegnante)
Reaction of the audience
(La reazione del pubblico)

4.4.7 How did you Feel after you Gave your English Presentation/speech in Front of the Class?

Come ti sei sentito dopo avere fatto la tua presentazione/tenuto il discorso di fronte alla tua classe?

I was proud of myself because I coped with my fear of public speaking

(Ero orgoglioso perché avevo fatto affrontato la paura di parlare in pubblico)

I felt uneasy because I had not been able to do well

(Mi sentivo a disagio perché non ero stato in grado di fare bene)

I felt relieved because it was over

(Mi sentivo sollevato perché era finita)

I felt happy because my English had been quite good

(Ero contento perché il mio inglese era stato piuttosto buono) 
4.4.8 Do you Think that Giving Presentations and Speeches is

Pensi che fare una presentazione o tenere un discorso sia:

A good way to practice the language

(Un buon modo per esercitare la lingua)

A useful way to become familiar with speaking in front of others

(Un modo utile per familiarizzare con il parlare in pubblico)

A waste of time from the point of view of learning the language

(Una perdita di tempo per quanto riguarda imparare la lingua)

A useless practice because I will rarely have to speak in front of an audience

(Un esercizio inutile perché raramente mi troverò a parlare in pubblico)

4.4.9 Optional Question: Are there any Suggestions you would Give the Teacher about the Course or just Outline Something Related to the Experience of Public Speaking that was not Expressed in any of the Previous Questions?

$\mathrm{Ci}$ sono suggerimenti che daresti all'insegnante relativamente al corso o semplicemente evidenzia qualcosa riguardo all'esperienza del public speaking che non è emerso nelle domande precedenti?

\section{Results}

As I have already outlined, this work cannot be exhaustive and is not aimed at establishing a golden rule, since it focuses on a personal experience that, however limited it may have been, can help contribute to formulate some hypotheses in the thorny issue of public speaking in EFL classes. The questionnaire provides the answers given anonymously by the students, who in some cases did not respond to a specific question. Therefore, the number of answers to each question does not necessarily represent the entirety of the students surveyed.

5.1 Do You Like Giving Public Presentations/Delivering A Speech in Your Native Language?

\begin{tabular}{lc}
\hline Yes & 11 \\
Not much & 8 \\
No & 0 \\
\hline Often Have You Given a Public Presentation/Delivering a Speech in Everyday Life? & \\
\hline Never & 3 \\
Rarely & 9 \\
Occasionally & 6 \\
Often or quite often & 1 \\
\hline
\end{tabular}

5.3 How did You Feel When You Were Offered to Give a Public Presentation in Your English Class?

Upset 0

Calm 4

\begin{tabular}{lr} 
Slightly nervous & 12 \\
\hline
\end{tabular}

Very nervous 3

5.4 How do You Usually Feel When You Have to Speak English?

I feel confident and relaxed 0

$\begin{array}{ll}\text { I feel slightly nervous but can cope } & 15\end{array}$

I get nervous and confused 4

$\begin{array}{ll}\text { I start to panic } & 0\end{array}$

5.5 How did You Feel When You Gave Your English Presentation/Speech in Front of the Class?

I felt confident and relaxed 2

$\begin{array}{ll}\text { I felt slightly nervous but could cope } & 15\end{array}$

$\begin{array}{ll}\text { I got nervous and confused } & 2 \\ \text { I started to panic } & \end{array}$

$\begin{array}{ll}\text { I started to panic } & 0\end{array}$ 
5.6 What was Your Main Difficulty in Giving your Presentation/Speech in Front of the Class?

\begin{tabular}{lc}
\hline Fear of speaking in public & 2 \\
Fear of speaking in English & 13 \\
Reaction of the teacher & 0 \\
Reaction of the audience & 4
\end{tabular}

5.7 How did You Feel after You Gave Your English Presentation/Speech in Front of the Class?

I was proud of myself because I coped with my fear of public speaking 8

I felt uneasy because I had not been able to do well 2

I felt relieved because it was over 2

$\begin{array}{ll}\text { I felt happy because my English had been quite good } & 7\end{array}$

5.8 Do You Think that Giving Presentations and Speeches is

$\begin{array}{ll}\text { A good way to practice the language } & 10\end{array}$

A useful way to become familiar with speaking in front of others 9

A waste of time from the point of view of learning the language 0

A useless practice because I will rarely have to speak in front of an audience 0

5.9 Optional Question: Are there any Suggestions you would Give the Teacher about the Course or just Outline Something Related to the Experience of Public Speaking that was not Expressed in any of the Previous Questions?

"For my part, I think that exercise was very useful to practice English because I hope that English will help me for my future work and for this reason, I would like to improve it for speak it better in front of an audience, or in other situations. In my opinion there are many advantages in this exercise, not only for learn more English but also in favour of own personality, because it is a good way to stimulate the individual to take on this new challenge".

"In my opinion it has been a useful experience, in order to gain linguistic confidence and to win the fear of public speaking. Furthermore, I think that it has made us socialize with our mates: now we know something more about them and it is great. It would have been nice having more time for a debate about the topics exposed, and not only a feedback about the performance".

It is important to mention first that 19 students out of 22 answered the questionnaire, corresponding to $86 \%$ of the sample. As emerges from question $1,42 \%$ of the respondents do not like public speaking very much, though nobody expresses complete dislike. More than half, instead (58\%) seem to like giving public presentations.

From question 2 we learn that $63 \%$ of them rarely or never practice public speaking. This supports the general idea that this activity is not so common in schools and universities and it could be the reason why some students do not like it or feel uneasy at the idea of putting it into practice. In fact, from question 3 we see that $79 \%$ of the surveyed students declare that they felt a sense of nervousness when they were told to give a presentation in English within the course ("slightly nervous" and "very nervous"). Also, in the answer to question 4 they claim that when they happen to speak English, they feel slightly nervous though they can cope (79\%). In this case they are not referring to a public speaking event but to any possibility of using English in everyday life.

In question 5, concerning their mental state during the performance, $89 \%$ of them stated that this feeling was present during the speech, though the majority managed to control it: "I felt slightly nervous but could cope".

It is worth noting how the students answered question 6 , focused on trying to identify their main difficulty in the performance. As emerges from their response, the main trouble encountered was "the fear of speaking English" for $68 \%$ of the sample. Only $10 \%$ of them answered "fear of speaking in public", whereas $21 \%$ feared the feedback of the audience, that is the reaction of their classmates.

Question number 7 outlines that a sense of achievement was the prevailing feeling after their performance, gained either by having coped with speaking before an audience or using good English.

Question 8 is significant because it shows that the experiment was considered useful from both points of view: use of English (52\%) and public speaking (47\%). Only two students decided to answer the optional question 9, an open-ended question enabling them to say something more detailed and personal about the experience. 


\section{Conclusions}

The following conclusions have been drawn: speaking English in public is a weakness that most students have acknowledged, since a sense of inadequacy seems to emerge from their answers but also from the feedback given during their performance in class. However, public speaking in English has proved to be useful since, after their performance students had positive feelings of success, satisfaction and pleasure. The old maxim "practice makes perfect" or at least, leads to a greater improvement, is always a good approach because the more students are exposed to using the language in public, the more they gain confidence in both English and soft-skills (organizational and communicative abilities). This seems to be highly encouraging and motivating for them and gives them a true-to-life context in which to practice and improve.

\section{References}

Balboni P. E. (1999). Parole comuni, culture diverse. Guida alla comunicazione interculturale, Venezia, Marsilio.

Cooke L.W. (2007). (ed.) Frontiers in Higher Education, Nova Science Publishers Inc, Hauppauge, NY.EF EPI. (2013). Education First English Proficiency Index.http://www.ef.com/_/ /media/efcom/epi/2014/full-reports/ef-epi-2013-report-master.pdf

Goffman E. (1959). The Presentation of Self in Everyday Life, New York, Doubleday.

Goffman E. (1967). Interaction Ritual: Essays on Face-to-Face Behaviour. Garolen City, New York: Anchor/Doubleday

ISTAT. (2014). L'uso della lingua italiana, dei dialetti $e$ di altre lingue in Italia. http://www.istat.it/it/files/2014/10/Lingua-italiana-eDialetti

Janulevičienè V., \& Kavaliauskienè G. (2012). The development of critical thinking skills through self-evaluation in a tertiary ESP course. Socialiniu mokslu studijos: mokslo darbai, 4(4), 1357-1370.

Kavaliauskienè, G. (2006). Good Practice in Teaching ESP Presentations. ESP World, 5(2), 13.

Liu M. (2006). Anxiety in Chinese EFL students at different proficiency levels. System, 34(3), 301-316. https://doi.org/10.1016/j.system.2006.04.004

Luo H. (2014). Foreign Language Speaking Anxiety: A Study of Chinese Language Learners. Journal of the National Council of Less Commonly Taught Languages, 15, 99-117.

Porcelli G. (2004). Comunicare in lingua straniera: Il lessico, UTET-Libreria, Torino

Rogers Carl. (1980). A Way of Being, Boston: Houghton Mifflin.

Souter N. (2007). Persuasive presentations: How to get the response you need. New York, USA: Sterling.

Tercan, G., \& Dikilitaş, K. (2015). EFL students' speaking anxiety: a case from tertiary level students. ELT Research Journal, 4, 16-27.

Yaikhong K., \& Usaha S. (2012). A Measure of EFL Public Speaking Class Anxiety: Scale Development and Preliminary Validation and Reliability. English Language Teaching, 5(12), 2012. https://doi.org/10.5539/elt.v5n12p23

Zhiping D., \& Paramasivam S. (2013). Anxiety of speaking English in class among international students in a Malaysian university in International Journal of Education and Research, 1(11), 1-16.

\section{Notes}

Note 1. Exchange effective messages, my translation (Balboni, p. 25).

Note 2. The Common European Framework of Reference for Languages: Learning, teaching, assessment (CEFR) is a framework of reference. It was meant to give a clear, coherent and thorough-testing basis for the elaboration of the language syllabus and curriculum guidelines, the structure of teaching and learning materials, and the assessment of foreign language skills.

Note 3. http://www.ef.com/__ / media/efcom/epi/2014/full-reports/ef-epi-2013-report-master.pdf (Last accessed, 21 May 2020).

Note 4. http://www.istat.it/it/files/2014/10/Lingua-italiana-eDialetti (Last accessed, 27 May 2020).

\section{Copyrights}

Copyright for this article is retained by the author(s), with first publication rights granted to the journal.

This is an open-access article distributed under the terms and conditions of the Creative Commons Attribution license (http://creativecommons.org/licenses/by/4.0/). 